\title{
PROBLEMATIKA PENEGAKAN HUKUMAN DISIPLIN KEPEGAWAIAN
}

Oleh :

Tedi Sudrajat

Fakultas Hukum Universitas Jenderal Soedirman Purwokerto

\begin{abstract}
This Article is mention to describe the existence of administrative law that inherent with the activity of public servants and it makes many consequences in the term of law enforcement. Based on the analysis of the administrative system, there are many problems in the structure, substance and culture of its legal system. The problems in those three aspects can be seen in the substance of President Regulation No.30 year 1980 that gave the opportunity for the infraction. The substance also influences the structure and the culture in the activity of the public servant.
\end{abstract}

Kata kunci : Administrasi Kepegawaian, Pegawai Negeri Sipil dan Pelanggaran Disiplin.

\section{A. Pendahuluan}

Pada era reformasi, upaya untuk mewujudkan sistem pemerintahan yang demokratis, bersih dan berwibawa telah menjadi prioritas utama bagi rakyat dan pemerintahan Indonesia. Reformasi birokrasi sebagai salah satu tuntutan reformasi telah menjadikan awal timbulnya kesadaran akan mekanisme birokrasi dan menjadi tonggak kesadaran pemerintah untuk menata sistem pemerintahan yang baik. Sejalan dengan perkembangan ilmu pengetahuan dan teknologi, saat ini telah terjadi perubahan yang mendasar berupa perwujudan tata pemerintahan yang demokratis dan baik (democratic and good governance). Dalam konsep good governance, Bappenas menjelaskan mengenai prinsip-prinsip yang harus dilaksanakan dalam mewujudkan tata pemerintahan yang baik, meliputi :

1. visoner;

2. transparan;

3. responsif;

4. akuntabel;

5. profesionalitas;

6. efisien dan efektif;

7. desentralisasi;

8. demokratis dan berorientasi pada konsensus;

9. partisipatif;

10. kemitraan;

11. supremasi hukum;
12. pengurangan kesenjangan;

13. komitemen pada pasar;

14. komitmen pada lingkungan hidup. ${ }^{1}$

Berdasar prinsip tersebut, maka birokrasi merupakan bagian penting dalam pelaksanaan fungsi pemerintahan guna menciptakan tata pemerintahan yang baik. Birokrasi sebagai front liner akan selalu berkaitan dengan pembinaan sumber daya manusia dalam pemerintahan dan karenanya akan timbul pergeseran paradigma dalam pelayanan publik yang secara otomatis menciptakan perubahan sistem dalam hukum kepegawaian meliputi penataan kelembagaan birokrasi pemerintahan, sistem, dan penataan manajemen kepegawaian. Pola pikir pengembangan hukum kepegawaian memiliki arti sebagai pergeseran paradigma dalam sistem pemerintahan untuk menjamin terselenggaranya tugas-tugas umum pemerintahan dan pembangunan secara berdaya guna dan berhasil guna dan dalam rangka upaya mewujudkan masyarakat yang adil dan makmur baik material maupun spiritual. ${ }^{2}$

Dalam konteks hukum kepegawaian, Pegawai Negeri Sipil sebagai unsur aparatur ne-

\footnotetext{
Bappenas, 2002. Tingkat Pemahaman Aparatur Pemerintah Terhadap Prinsip-Prinsip Tata Pemerintahan Yang Baik, Jakarta: Badan Perencanaan Pembangunan Nasional, hlm.2.

2 Warsito Utomo, 2006, Administrasi Publik Baru Indonesia; Perubahan Paradigma dari Administrasi Negara ke Administrasi Publik, Yogayakarta: Pustaka Pelajar, hlm.3
} 
214 Jurnal Dinamika Hukum

Vol. 8 No. 3 September 2008

gara memiliki peranan yang sentral dalam membawa komponen kebijaksanaan-kebijaksanaan dan peraturan-peraturan pemerintah. Peranan dari Pegawai Negeri Sipil seperti diistilahkan dalam dunia kemiliteran "not the gun, the man behind the gun" yaitu bukan senjata yang penting melainkan manusia yang menggunakan senjata itu. Senjata yang modern tidak mempunyai arti apa-apa apabila manusia yang dipercaya menggunakan senjata itu tidak melaksanakan kewajibannya dengan benar. ${ }^{3} \mathrm{Hal}$ ini berarti bahwa Pegawai Negeri Sipil merupakan tulang punggung pemerintahan dalam melaksanakan fungsi pelayanan dan pembangunan nasional.

Berdasarkan hal di atas, maka kedudukan dan peranan Pegawai Negeri Sipil akan berkaitan erat dengan hak dan kewajiban yang melingkupi aktivitasnya. Apabila hak telah diperoleh namun kewajiban tidak dilaksanakan, secara otomatis Pegawai Negeri Sipil tersebut akan dikenakan sanksi. Hal tersebut merupakan konsekuensi dari openbare dienstbetrekking (hubungan dinas publik) yang melekat pada hubungan kepegawaian sebagai hubungan subordinatie antara bawahan dan atasan. ${ }^{4}$ Menurut Logemann, hubungan dinas publik adalah bilamana seseorang mengikat dirinya untuk tunduk pada perintah dari pemerintah untuk melakukan sesuatu atau beberapa macam jabatan yang dalam melakukan suatu atau beberapa macam jabatan itu dihargai dengan pemberian gaji dan beberapa keuntungan lain. Inti dari hubungan dinas publik adalah kewajiban bagi pegawai yang bersangkutan untuk tunduk pada pengangkatan dalam beberapa macam jabatan tertentu yang berakibat bahwa pegawai yang bersangkutan tidak menolak (menerima tanpa syarat) pengangkatannya dalam satu jabatan yang telah ditentukan oleh pemerintah di mana sebaliknya pemerintah berhak mengangkat seseorang pegawai dalam jabatan tertentu tanpa harus adanya penyesuaian kehendak dari

\footnotetext{
3 Muchsan, 1982, Hukum Kepegawaian, Jakarta : Bina Aksara, ,hlm.12

4 Philipus M.Hadjon., Philipus M Hadjon, dkk, 1994, Pengantar Hukum Administrasi Indonesia, Yogyakarta : Gadjah Mada University Press, hlm.214
}

yang bersangkutan. ${ }^{5}$ Hubungan dinas publik inipun berkaitan dengan segi pengangkatan Pegawai Negeri yang dikenal dengan teori Contrac Suigeneris. Contrac Suigeneris berarti bahwa pegawai negeri harus setia dan taat selama menjadi Pegawai Negeri, meskipun dia setiap saat dapat mengundurkan diri. ${ }^{6}$

Teori di atas menekankan bahwa kewajiban melaksanakan tugas negara merupakan intisari dari kepegawaian, dan apabila kewajiban tersebut dilanggar akan dikenakan sanksi. Artinya, terdapat kesebandingan antara hak yang didapat oleh Pegawai Negeri Sipil dengan kewajiban yang harus dilaksanakan. John Rawls berpendapat bahwa fungsi dari hukum adalah menetapkan hak dan kewajiban secara berimbang. Oleh karena itu kebebasan harus disertai dengan kesadaran akan tanggung jawab. Tanpa keseimbangan kewajiban dan tanggung jawab, kebebasan dapat membawa manusia ke dalam peradaban rimba di mana berlaku prinsip the survival of the strongest. Tanpa adanya tanggung jawab sebagai kewajiban yang tak terpisahkan dari hak atas kebebasan dapat saja menjungkirbalikkan situasi sosial. ${ }^{7}$ Berdasar hal tersebut, maka pemerintah membuat peraturan disiplin PNS untuk memperbaiki dan mendidik Pegawai Negeri Sipil yang melakukan pelanggaran disiplin agar tidak diulang kemudian hari. ${ }^{8}$

Tulisan ini bermaksud untuk menggambarkan bahwa keberadaan hukum kepegawaian itu inheren dalam aktivitas kepegawaian. Struktur keberadaan yang demikian itu menyebabkan penegakan hukum harus selaras dengan konsepsi yang dibangun dan karenanya aspek penegakan sanksi hukuman disiplin haruslah seimbang. Namun berdasarkan analisis terhadap sistem penegakan hukuman disiplin

\footnotetext{
5 S.F. Marbun dan M. Mahfud MD, 1987, Pokok-Pokok Hukum Administrasi Negara, Yogyakarta : Liberty, hlm. 98-99.

$6 \mathrm{lbid}, \mathrm{hlm} .99-100$

7 Andre Ata Ujan, 2005, Keadilan dan Demokrasi; Telaah Filsafat Politik John Rawls, Yogyakarta : Penerbit Kanisius, hlm. 149

8 Soekarno, 1983, Himpunan Soal jawab Kepegawaian negeri Sipil (Hak dan Kewajiban), Jakarta : Miswar, hlm.219.
} 
kepegawaian, timbul permasalahan terhadap struktur hukum, substansi hukum dan budaya hukumnya. Berdasarkan ketiga aspek tersebut, dapat diketahui bahwa sistem yang dibangun dalam PP No.30 tahun 1980 tentang Peraturan Disiplin PNS telah memberikan celah terhadap terjadinya pelanggaran dan pembiaran terhadap pelanggaran, oleh karena itu sangat wajar jika hukuman disiplin kepegawaian sulit untuk ditegakkan.

\section{B. Pengaturan Tentang Disiplin Pegawai Negei Sipil}

Dalam lingkungan Pegawai Negeri Sipil, guna menjamin tata tertib dan kelancaran pelaksanaan tugas pekerjaan telah dibuat suatu ketentuan tentang disiplin Pegawai Negeri Sipil. Ketentuan tersebut diatur dalam Peraturan Pemerintah Nomor 30 tahun 1980 tentang Peraturan Disiplin Pegawai Negeri Sipil dan ketentuan pelaksanaannya ditetapkan dalam Surat Edaran Kepala Badan Administrasi Kepegawaian Negara No.23/SE/1980 Tahun 1980. Ketentuan ini membahas tentang kewajiban yang harus dilakukan Pegawai Negeri Sipil, larangan serta jenis-jenis hukuman.

Penetapan sanksi terhadap pelanggaran disiplin PNS merupakan konsekuensi terhadap bentuk pelanggaran yang dilakukan oleh $\mathrm{Pe}$ gawai Negeri Sipil dalam melaksanakan tugasnya. Jadi, bentuk evaluasi kinerja merupakan upaya yang dilakukan pemerintah dalam melaksanakan fungsi pengawasan terhadap perilaku PNS yang tujuannya adalah untuk menjaga kredibitas, harkat dan martabat PNS di mata masyarakat. Hal ini menjadi penentu baikburuknya keberadaan PNS, dengan pengawasan dan penetapan sanksi yang baik maka secara otomatis oknum-oknum PNS akan evaluasi dan diberikan sanksi yang sesuai peraturan dan akhirnya pelayanan publik akan menjadi semakin baik.

Menurut Pasal 1 huruf a PP No.30 Tahun 1980 , pengertian dari peraturan disiplin adalah peraturan yang mengatur kewajiban, larangan, dan sanksi, apabila kewajiban tidak ditaati atau larangan dilanggar oleh PNS. Pelanggaran disiplin adalah setiap ucapan, tulisan, atau perbuat- an PNS yang melanggar ketentuan Peraturan Disiplin PNS baik yang dilakukan di dalam maupun diluar jam kerja. Pengertian dari tulisan adalah pernyataan pikiran dan atau perasaan secara tertulis baik dalam bentuk tulisan maupun dalam bentuk gambar, karikatur, coretan dan lain-lain yang serupa dengan itu. Ucapan adalah setiap kata-kata yang diucapkan di hadapan atau dapat didengar oleh orang seperti dalam rapat, ceramah, melalui telepon, TV atau alat komunikasi lainnya. Perbuatan adalah setiap tingkah laku, sikap atau tindakan.

Berdasarkan hal tersebut, maka setiap pelanggaran yang dilakukan oleh PNS akan menimbulkan konsekuensi berupa hukuman. Jenis-jenis hukuman disiplin bagi Pegawai Negeri Sipil yang melanggar terdapat dalam Pasal 6 ayat (1) PP No.30 tahun 1980 yang terdiri dari :

1. Hukuman disiplin ringan;

2. Hukuman disiplin sedang;

3. Hukuman disiplin berat.

Menurut Pasal 6 ayat (2) PP No. 30 Tahun 1980 , jenis hukuman ringan terdiri dari:

1. Tegoran lisan;

2. Tegoran tertulis;

3. Pernyataan tidak puas secara tertulis.

Pasal 6 ayat (3) PP No.30 tahun 1980, jenis hukuman sedang terdiri dari:

1. Penundaan kenaikan gaji berkala untuk paling lama 1 (satu) tahun;

2. Penurunan gaji sebesar satu kali kenaikan gaji berkala untuk paling lama 1 (satu) tahun;

3. Penundaan kenaikan pangkat untuk paling lama 1 (satu) tahun.

Pasal 6 ayat (4) PP No.30 tahun 1980, jenis hukuman berat terdiri dari :

1. Penurunan pangkat pada tingkat yang setingkat lebih rendah untuk paling lama 1 (satu) tahun;

2. Pembebasan dari jabatan;

3. Pemberhentian dengan hormat tidak atas permintaan sendiri sebagai PNS;

4. Pemberhentian tidak dengan hormat sebagai PNS. 
216 Jurnal Dinamika Hukum

Vol. 8 No. 3 September 2008

Sedangkan prinsip-prinsip yang digunakan dalam penjatuhan hukuman disiplin adalah:

1. Prinsip keadilan

Pejabat yang berwenang menghukum harus mempertimbangkan hal-hal yang memberatkan dan meringankan atas kesalahan yang dilakukan PNS.

2. prinsip kemanfaatan

Sanksi yang dijatuhkan harus bermanfaat untuk mendidik dan memperbaiki PNS yang dikenai sanksi serta berdampak positif bagi lingkungan kerja.

3. prinsip konsistensi

Sanksi/penindakan yang sudah pernah di jatuhkan dijadikan pedoman untuk menjatuhkan sanksi atas kasus yang sama dengan tetap mempertimbangkan prinsip-prinsip penjatuhan sanksi lainnya.

4. prinsip kepastian hukum

Kepastian hukum disini berarti pelanggaran sekecil apapun tetap dikenakan sanksi hukuman terhadap PNS yang melanggarnya.

\section{Hukuman Disiplin Kepegawaian dan Permasalahannya}

Secara teoretis, fungsi pokok dari hukum adalah mengatur hubungan antarmanusia dan antara individu dengan negara agar segala sesuatu berjalan dengan tertib sehingga kedamaian karena tegaknya kepastian (hukum) dan keadilan di dalam masyarakat, yang notabene merupakan tujuan hukum dapat tercapai. ${ }^{9}$ Berdasar hal tersebut, menurut Radbruch, hukum seharusnya memenuhi nilainilai dasar yang meliputi keadilan, kegunaan (zweekmaszigkeit) dan kepastian hukum. Berdasarkan perspektif tersebut, maka penegakan hukum hendaklah dilihat sebagai suatu proses sosial yang melibatkan lingkungannya, dalam pengertian bahwa penegakan hukum sebagai kegiatan yang menarik lingkungan ke dalam proses tersebut, maupun yang harus menerima pembatasan-pembatasan dalam bekerjanya di

\footnotetext{
9 Soerjono Soekanto dalam Agus Dwiyanto, dkk, 2003, Teladan dan Pantangan Dalam Penyelenggaraan Pemerintahan Dan Otonomi Daerah, Yogyakarta : Galang Printika, hlm. 91.
}

sebabkan oleh faktor lingkungan. Penegakan hukum dilihat sebagai kegiatan untuk mewujudkan keinginan-keinginan hukum menjadi kenyataan. Artinya, sebagai usaha untuk mewujudkan nilai-nilai dasar di dalam hukum seperti keadilan, kepastian hukum dan kemanfaatan. Namun permasalahannya adalah sekalipun ketiga-ketiganya merupakan nilai dasar dari hukum, namun diantara ketiganya terdapat spannungsverhaltnis, suatu ketegangan satu sama lain. ${ }^{10}$

Berbicara tentang problematika penegakan hukuman disiplin kepegawaian, maka di dalam Hukum Kepegawaian terdapat juga spannungsverhaltnis antara unsur kepastian, keadilan dan kemanfaatan hukum. Karenanya permasalahan tersebut akan dilihat dan dianalisis melalui aspek (1) struktur hukum, (2) substansi hukum, dan (3) budaya hukum.

Komponen pertama yang dianalisis adalah struktur hukum. Menurut Lawrence M. Friedman, yang dimaksud dengan suatu struktur sistem hukum adalah:

... its skeleton or framework, the durable part, which gives a kind of shape and definition to the whole.... The structure of a legal system consists of elements of this kind: the number and size of courts; their jurisdiction (that is, what kind of cases they hear, and how and why); and modes of appeal from one court to another. Structure also means how the legislature is organized, how many members..., what a president can (legally) do or not do, what procedures the police department follows, and so on. Structure, in a way, is a kind of cross section of the legal system? a kind of still photograph, which freezes the action. ${ }^{11}$

Struktur hukum dalam konteks kepegawaian adalah pejabat yang berwenang menghukum, meliputi :

1. Presiden, bagi pelanggar PNS yang :

\footnotetext{
${ }^{10}$ Satjipto Rahardjo, 2006, Ilmu Hukum, Bandung : Citra Aditya Bakti, hlm.19.

${ }^{11}$ Lawrence M. Friedman, 1984, American Law: An Introduction New York:W.W. Norton \& Co., , hlm. 5
} 
a) Berpangkat Pembina Tingkat I (Gol IV/b ke atas) sepanjang mengenai jenis hukuman berat (Pasal 6 ayat (4) huruf $c$ dan d)

b) Yang memangku jabatan struktur Eselon I (Khusus untuk membebaskan jabatan).

2. Menteri, untuk semua jabatan struktural Eselon I (khusus untuk membebaskan jabatan);

3. Pejabat yang berwenang (menteri) dapat mendelegasikan wewenang kepada pejabat lain (kecuali untuk Pasal 6 ayat (4) huruf c dan d) dengan ketentuan :

a) Untuk hukuman disiplin ringan, dapat didelegasikan kepada eselon IV

b) Untuk hukuman disiplin ringan dan sedang (penundaan kenaikan gaji berkala), dapat didelegasikan kepada eselon III

c) Untuk hukuman disiplin ringan dan sedang kepada Eselon II

d) Untuk hukuman disiplin ringan, sedang dan berat (kecuali huruf $c$ dan d) kepada Eselon I

4. Gubernur, dapat memerintahkan pejabat bawahannya untuk memeriksa PNS yang disangka

5. Perwakilan RI di luar negeri

6. Bupati/walikota seperti yang diatur dalam UU No.32 Tahun 2004 tentang Pemerintahan daerah.

Melihat dan menyikapi poin-poin di atas, maka dapat diketahui bahwa dalam proses pemeriksaan dugaan pelanggaran sampai dengan proses memutus jenis hukuman yang sifatnya ringan dan sedang, pejabat dilingkungan pusat mendelegasikan kewenangannya kepada departemen atau instansi dibawahnya. Melalui mekanisme tersebut, secara struktural pejabat yang berwenang menghukum adalah atasan langsung dari si pelanggar. Artinya, penjatuhan hukuman dilakukan oleh pejabat yang notabene merupakan bagian dalam lingkungan kerja. Hal ini menimbulkan asumsi bahwa si pejabat yang memutus dan si pelanggar merupakan bagian dalam sistem yang mempunyai ikatan emosional dan psikologis dalam lingkungan kerjanya. Hal ini akan menimbulkan permasalahan dalam hal penjatuhan hukuman yang cenderung ke arah subjektivitas, apalagi ditambah pula dengan substansi dari pasal 6 PP No.30 tahun 1980 yang tidak menentukan kriteria/parameter dalam hal penentuan dan penjatuhan jenis pelanggaran. Menurut Feisal Tamin, penegakan hukum dipengaruhi oleh lingkungan kerja yang bersikap toleran (permisif) terhadap pelanggaran-pelanggaran disiplin PNS, karena sebagai bagian integral dari kepribadian, disiplin itu tidak terlepas dari pembentukan pribadi manusia secara keseluruhan. ${ }^{12}$ Berdasar hal tersebut, maka struktur hukum yang di bangun dalam sistem penjatuhan hukuman disiplin tersebut akan mempengaruhi penegakan hukum dan karenanya diperlukan sistem penjatuhan hukuman yang netral dan independen.

Komponen kedua dari sistem hukum adalah substansi, yaitu “... the actual rules, norms, and behavior patterns of people inside the system."13 Definisi ini menunjukkan pemaknaan substansi hukum yang lebih luas daripada sekadar stelsel norma formal (formele normenstelsel). Friedman memasukkan pula pola-pola perilaku sosial dan norma-norma sosial selain hukum, sehingga termasuk juga etika sosial seperti asas-asas kebenaran dan keadilan. Jadi, yang disebut komponen substansi hukum di sini adalah semua asas dan norma yang dijadikan acuan oleh masyarakat dan pemerintah.

Untuk melihat sebuah peraturan mempunyai substansi hukum yang baik atau tidak, maka dapat diuji melalui syarat-syarat pembuatan hukum yang efektif meliputi:

1. Peraturan dirancang dengang baik, kaidahnya jelas, mudah dipahami dan penuh kepastian.

2. Peraturan sebaiknya bersifat melarang (prohibitur) dan bukan mengharuskan/membolehkan (mandatur).

3. Sanksi haruslah tepat dan sesuai tujuan.

4. Beratnya sanksi tidak boleh berlebihan (sebanding dengan pelanggarannya).

\footnotetext{
${ }^{12}$ Feisal Tamin, 2004, Reformasi Birokrasi ; Analisis Pendayagunaan Aparatur Negara, Jakarta : Belantika, $\mathrm{h} \mathrm{lm} .118$.

${ }^{13}$ Ibid, hlm..6
} 
218 Jurnal Dinamika Hukum

Vol. 8 No. 3 September 2008

5. Mengatur terhadap perbuatan yang mudah dilihat.

6. Mengandung larangan yang berkesesuaian dengan moral.

7. Pelaksana hukum menjalankan tugasnya dengan baik, sosialisasi peraturan, dan penafsiran seragam dan konsisten. ${ }^{14}$

Berdasar hal di atas, maka terdapat permasalahan mendasar dalam Pasal 6 PP No. 30 tahun 1980 dimana di dalam pasal tersebut hanya disebutkan jenis-jenis pelanggaran disiplin saja, tanpa mencantumkan dan menjelaskan kriteria yang dapat dijadikan dasar untuk memutuskan sanksi, artinya bentuk aktivitas seperti apakah yang dapat diancam dengan hukuman disiplin ringan, sedang atau berat. Hal ini mengandung arti bahwa peraturan tersebut tidak memenuhi syarat hukum yang efektif karena :

1. Kaidah hukumnya tidak jelas;

2. Menimbulkan penafsiran yang berbeda bagi setiap pejabat yang berwenang;

3. Sanksi yang diberikan dirasakan tidak tepat dikarenakan penentuan pelanggaran yang ditujukan dalam PP tersebut masih belum jelas;

4. Menimbulkan ketidakpastian hukum dalam penjatuhan hukuman.

Komponen ketiga dari sistem hukum adalah budaya hukum, yang diartikan oleh Friedmann sebagai:

... people's attitudes toward law and legal system/their beliefs, values, ideas, and expectations. . . The legal culture, in other words, is the climate of social thought and social force which determines how law is used, avoided, or abused. Without legal culture, the legal system is inert? a dead fish lying in a basket, not a living fish swimming in its sea. ${ }^{15}$

\footnotetext{
${ }^{14}$ Robert Biersted, 1970, The Social Order, Tokyo: Mac Graw Hill Kogakusha Ltd, p. 227-229.

15 Ibid
}

Budaya hukum dapat diberikan batasan yang sama dengan kesadaran hukum. ${ }^{16}$ Kesadaran hukum adalah abstraksi (para ahli) mengenai perasaan hukum dari para subjek hukum. Dalam konteks pembicaraan tentang sistem hukum ini, tentu saja yang dimaksud dengan budaya hukum adalah kesadaran hukum dari subyek-subyek hukum suatu komunitas secara keseluruhan. ${ }^{17}$ Jadi, sekalipun struktur hukum (pejabat yang berwenang) dan substansi hukum (PP No.30 tahun 1980) bekerja dan berlaku untuk seluruh PNS, tetap saja terbuka kemungkinan adanya perbedaan tentang pola kerja dan penerapan hukumnya. Hal ini terjadi karena ada interaksi antara aparat penegak hukum, hukum yang berlaku, dan budaya kerja yang terbangun. Dalam hal ini, faktor budaya kerja PNS dapat dikategorikan sebagai permasalahan yang harus diberikan perhatian khusus dalam sistem kepegawaian Indonesia.

Berdasarkan data dari Badan Kepegawaian Daerah Kabupaten Banyumas, jenis pelanggaran disiplin yang berkaitan dengan budaya kerja dan sering dilakukan PNS meliputi :

1. Terlambat masuk kantor tanpa alasan yang jelas dan masuk akal;

2. Pulang kantor lebih awal tanpa alasan yang jelas dan masuk akal, tanpa ijin atasan;

3. Selama jam kantor tidak melaksanakan pekerjaan (keluar kantor untuk tujuan diluar kedinasan/urusan pribadi);

4. Mangkir/tidak masuk kerja tanpa alasan yang jelas dan masuk akal;

5. Menyalahgunakan wewenang;

6. Melakukan hubungan intim/perselingkuhan. ${ }^{18}$

Berdasarkan data tersebut, dapat dianalisis bahwa terjadinya pelanggaran dikarenakan:

1. Lingkungan kerja yang bersifat toleran (permisif). Adanya suatu pengaruh yang signifikan antara kondisi lingkungan kerja

\footnotetext{
${ }^{16}$ Darji Darmodiharjo dan Shidarta, 1996, Penjabaran NilaiNilai Pancasila dalam Sistem Hukum Indonesia. Jakarta: Raja Grafindo Persada, hlm. 154.

17 J.J. von Schmid dalam C.F.G. Sunaryati Hartono, 1976, Peranan Kesadaran Hukum Masyarakat dalam Pembaharuan Umum. Bandung: Binacipta, hlm. 3.

18 Data dari Badan Kepegawaian Daerah Kabupaten Banyumas Tahun 2007
} 
dengan budaya kerja, dalam arti kecenderungan pegawai untuk membiarkan terjadinya pelanggaran karena menganggap bahwa hal tersebut merupakan perbuatan yang masih dapat ditolerir.

2. Adanya pengaruh yang signifikan antara fungsi penerapan hukum dengan perbuatan pegawai yang melanggar peraturan, karena kurangnya pengawasan sehingga dapat diasumsikan bahwa :

a. Kurang responnya aparat terhadap sanksi, lemahnya sistem controlling dan evaluating dari pihak yang terkait sehingga membiarkan pelanggaran terjadi.

b. Terdapatnya motivasi yang kurang dari PNS dikarenakan sistem yang tidak mewajibkan setiap pegawai untuk bekerja mengejar keuntungan bagi instansi sehingga tidak menuntut mereka untuk saling memberikan prestasi karena hasil yang diterima setiap bulannya relatif tidak berubah. Hal ini berimbas pada kinerja yang hanya berorientasi pada hasil, dan bukan pada proses penyelenggaraan pemerintahan yang menuntut adanya totalitas dalam pelaksanaan tugasnya. Pengaruh dari kurangnya motivasi tersebut membuat pihak penyelenggara pemerintahan hanya menjalankan formalitas tugasnya untuk mengisi jadwal kehadiran kerja dan bekerja dalam artian mengejar dateline suatu tugas tanpa memperhatikan tujuan yang diharapkan. Menurut Basir Barthos, budaya kerja orang Indonesia yang selama ini pernah diamati serta diteliti, masih kurang menghargai efisiensi dan disiplin kerja. Hal ini berbeda dengan orang Jepang dan orang-orang lain di negara Barat yang umumnya berciri positif dalam segi etos kerjanya menyangkut efisiensi, disiplin, sadar pentingnya waktu, menghargai inisiatif individu atau kemandirian. ${ }^{19}$

Berdasarkan hal di atas dapat diketahui bahwa aspek struktur, substansi dan budaya

\footnotetext{
${ }^{19}$ Bashir Barthos, 1990, Manajemen Sumber Daya Manusia, Suatu Pendekatan Makro, Jakarta ; Bumi Aksara, hlm. 112.
}

hukum sangat mempengaruhi penegakan hukuman, oleh karena itu paradigma yang dibangun dalam hukum kepegawaian haruslah dirubah sesuai dengan konteks yang kekinian.

\section{Penutup}

Penegakan hukuman disiplin kepegawaian dipengaruhi oleh struktur hukum, substansi hukum dan budaya hukumnya.

1. Dari aspek struktur hukum, mekanisme penjatuhan hukuman yang sifatnya ringan dan sedang sulit untuk diterapkan pada si pelanggar karena dipengaruhi oleh sistem delegasi secara hierarkis dan struktural.

2. Dari aspek substansi hukum, PP No.30 tahun 1980 tersebut tidak memenuhi syarat-syarat hukum yang efektif karena kaidah hukumnya tidak jelas, menimbulkan penafsiran yang berbeda bagi setiap pejabat yang berwenang, sanksi yang diberikan dirasakan tidak tepat dikarenakan penentuan pelanggaran yang ditujukan dalam PP tersebut masih belum jelas serta menimbulkan ketidakpastian hukum dalam penjatuhan hukuman.

3. Dari aspek budaya hukum, adanya pengaruh antara kondisi dalam lingkungan kerja dengan budaya kerja, dalam arti kecenderungan sesama pegawai untuk membiarkan terjadinya pelanggaran (budaya permisif), hal ini didukung pula dengan kurangnya fungsi kontrol dan evaluasi terhadap pelanggaran.

Untuk menegakkan hukuman disiplin diperlukan sistem hukum yang baik dengan cara merubah paradigma dalam hukum kepegawaian yang bukan hanya berorientasi pada pelaksanaan tugas namun berorientasi untuk memenuhi kebutuhan masyarakat. Hal ini akan berkaitan dengan prinsip meritokrasi dimana inti dari prinsip ini adalah jenis penguatannya (reinforcement) melalui reward dan punishment. Prinsip tersebut akan mengarah pada penegakan hukuman disiplin yang natural dan berimbang, yang didalamnya akan terkandung aspek kompetisi dan aspek peningkatan kualitas SDM aparatur yang berorientasi untuk memenuhi kebutuhan masyarakatnya. 


\section{Daftar Pustaka}

Bappenas. 2002. Tingkat Pemahaman Aparatur Pemerintah Terhadap Prinsip-Prinsip Tata Pemerintahan Yang Baik. Jakarta: Badan Perencanaan Pembangunan Nasional;

Barthos, Bashir. 1990. Manajemen Sumber Daya Manusia, Suatu Pendekatan Makro. Jakarta: Bumi Aksara;

Biersted, Robert. 1970. The Social Order. Tokyo: Mac Graw Hill Kogakusha Ltd;

Darmodiharjo, Darji dan Shidarta. 1996. Penjabaran Nilai-Nilai Pancasila dalam Sistem Hukum Indonesia. Jakarta: Raja Grafindo Persada;

Dwiyanto, Agus, dkk. 2003, Teladan dan Pantangan Dalam Penyelenggaraan Pemerintahan Dan Otonomi Daerah. Yogyakarta: Galang Printika;

Friedman, Lawrence M. 1984. American Law: An Introduction. New York: W.W. Norton \& Co;

Hadjon, Philipus M. dkk. 1994. Pengantar Hukum Administrasi Indonesia. Yogyakarta: Gadjah Mada University Press;

Hartono, C.F.G. Sunaryati. 1976. Peranan Kesadaran Hukum Masyarakat dalam Pembaharuan Umum. Bandung: Binacipta;

Marbun, S.F. dan M. Mahfud MD. 1987. PokokPokok Hukum Administrasi Negara. Yogyakarta: Liberty;

Muchsan. 1982. Hukum Kepegawaian. Jakarta : Bina Aksara;

Rahardjo, Satjipto. 2006. Ilmu Hukum. Bandung: Citra Aditya Bakti;

Soekarno. 1983. Himpunan Soal jawab Kepegawaian Negeri Sipil (Hak dan Kewajiban). Jakarta : Miswar;

Tamin, Feisal. 2004. Reformasi Birokrasi; Analisis Pendayagunaan Aparatur Negara. Jakarta: Belantika;

Ujan, Andre Ata. 2005. Keadilan dan Demokrasi; Telaah Filsafat Politik John Rawls. Yogyakarta : Penerbit Kanisius;

Utomo, Warsito. 2006. Administrasi Publik Baru Indonesia; Perubahan Paradigma dari
Administrasi Negara ke Administrasi Publik. Yogayakarta: Pustaka Pelajar. 